wondrous faculty, which, left to ramble uncontrolled, leads us astray into a wilderness of perplexities. and errors, a land of mists and shadows; but which, properly controlled by experience and reflection, becomes the noblest attribute of man; the source of poetic genius, the instrument of discovery in Science, without the aid of which Newton would never have invented fluxions, nor Davy decomposed the earths or the alkalies, nor would Columbus have found another continent."

Only one defect of classical instruction has been discussed. There are several others. The philosophical speculations of traditional Hellenism and the mechanical memorizing and formalism of medieval scholasticism have dominated educational schemes for centuries. Such a system of instruction has been tried and found wanting-it has masqueraded. under the name of education. Let our educational aims be more worthy and appreciative of our glorious English literature, more adapted to human needs, and a study of Christian rather than pagan principles. The English language and literature, together with the arts and sciences (including mathematics) and the cultivation of a sound body, provide the basis of a complete and balanced education and a generous culture.

\section{RHEOLOGY IN THE TEXTILE, LEATHER, SHOE AND ALLIED TRADES}

\begin{abstract}
$\mathrm{A}$
T a meeting of the British Rheologists' Club, held at Loughborough College on September 18, papers were read by Mr. A. Pollard, Dr. C. A. Maunder Foster, Mr. A. March, Mr. P. Danby and Mr. P. Stanley Briggs, and there was a discussion under the general title of "Rheology in the Textile, Leather, Shoe, and Allied Trades". It is convenient to deal with the proceedings in sections.
\end{abstract}

\section{Textiles}

In weaving, two banks of multiple warp threads are opened ('shedding'), a shuttle holding a single weft thread is passed through the 'shed' ('picking'), and a comb-like reed forces the weft into place ('beating'). The next 'shedding' operation locks the weft into place. Small inaccuracies in these three locating operations are, with staple material, partially corrected by the hairy projections from the yarn. With a smooth yarn such as rayon, which is solid rather than tubular, better location is needed; and the low 'tenacity' of the material calls for less alteration of stress than occurs in the normal 'broadcloth' loom.

In one modern ribbon loom, attention was given to these matters; warp tension was kept constant (the healds moving over the arc of a circle, centred at the line of the weft), the beating reed was given a very low amplitude, and all moving parts of the machine were very exactly controlled. Besides giving accurate and reproducible weaves, the output-rate of this machine is of the order of 1,000 'picks' per minute, or some $4-5$ times normal speed of production.

A poor view was taken at the meeting of the engineering ability of many designers and builders of textile machinery in general. One assertion was made, that 'tenacity' of yarn (breaking strain in ounces per denier) does not necessarily measure its probable behaviour in weaving.

\section{Shoemaking}

Great use is made of stitching: upper construction; joining of lining to upper, of upper to insole; of insole to welt, and of welt to outsole. Each of these operations is alike in outline; but as each unit process of the stitching differs according to the particular job, a whole range of machine designs, of awls, needles, shuttle threads, and of sewing threads is required.

For lubricant, the hand cobbler uses beeswax; shuttle threads are waxed; sewing threads are rosined; and the material which, in the making operation, acts as lubricant, after cooling down seals the holes and preserves the threads.

In toe, and in heel, reinforcement is used. For this purpose the toe 'puff' may ke shoddy cloth, sized with pitch or pyroxylin; or, for miners' boots, it may be steel. The toe-cap, puff reinforcement and lining must suffer the drafting strains of pulling on to a rigid wooden last; and thereafter must retain shape, and hold together as a unit.

The stiflener for the heel part is required to be rigid at its meridian, thin and fexible at its top edge.

After the shoe has been lasted, there is a hollow space under the middle of the insole; this must be suitably filled with a composition having resilience, before the outsole can be sewn or stuck on. Thus, the foundation of the average shoe is a "sandwich" of leather insole; cork composition or felt filler, and leather or rubber outsole. Should the filler be too soft, it will shift under the pressure of the foot, to give lumps and hollows in the insole surface which will be uncomfortable in wear.

Resilience, deformability, flexibility and the like are most often judged by the test of the trained finger-and-thumb. It would be desirable to have an artificial digital assembly, not subject to fatigue (or to prejudice), for these purposes.

In the operation of shoe-building, rubbery adhesives are largely used. The processes are repetitive, mechanical, and output is very large (the standard figure for the United Kingdom is rather less than 100 million pairs annually).

The adhesive maker needs, therefore, to maintain a steady consistency in his products; and this task is not simple with some of the present-day materials. For example, with a falling sphere viscometer, a thick paste of reclaim rubler solution may appear to have both thixotropic and dilatant properties. In a case such as this, trials were made, using a rotation viscometer, to obtain a consistent reading, so that a method might be available for works use. Rotation times were taken with different loads, after various periods of stirring. Constant time for a single turn was attained in a typical experiment on a Störmer instrument, after sixteen turns. Provided the load was above a certain lower limit (2 kgm.) :

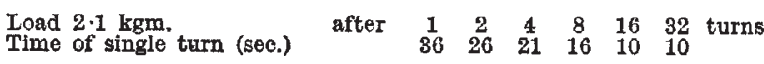

Restoration of the system to the former high viscosity figure could not ke completed: after 100 hours it was still slowly increasing, in linear fashion.

For measurements on this kind of stuff, the torsional viscometer was recommended as more suitable. 


\section{Leather Finishes}

The last treatment of leather, prior to sending to the warehouse, is to apply pigmented and dyed dressings or colourless seasons to the front surface (which is normally the grain side, but sometimes is the flesh side). The finishes used for this effect should have properties approximately the same as the surface layers of the leather to which they are bonded.

Some 50 per cent of the leather substance is animal protein in nature; the rest being added material of diverse origin. Animal protein likewise forms the main basis of leather finishes; with wax, shellac, pigment, grease and sulphated oil as the other ingredients, all dispersed in water.

So that the behaviour of the finishing materials under strains of the sort to which leather is subject might be studied, isolated films were stressed to the break-point. These films, between $10 \mu$ and $15 \mu$ thick, were cast on a rubber substratum, conditioned some days at 70 per cent relative humidity, and test pieces cut and stretched at a steady rate. Typical figures were:

\begin{tabular}{|c|c|c|c|c|c|}
\hline $\begin{array}{l}\text { Elongation } \\
\% \text { at break }\end{array}$ & Casein & Sheliac & $\begin{array}{l}\text { Casein 4: } \\
\text { Shellac } 1\end{array}$ & $\begin{array}{l}\text { Casein 4: } \\
\quad \text { Wax } 1\end{array}$ & $\begin{array}{c}\text { Casein 9: } \\
\text { Pigment } 1 \\
75\end{array}$ \\
\hline \multicolumn{6}{|c|}{ Casein plasticized with sulphated oil } \\
\hline Elongation & $1 \%$ & $2 \%$ & $4 \%$ & $8 \%$ & \\
\hline$\%$ at break & 230 & 250 & 310 & 350 & \\
\hline
\end{tabular}

The optimum flgure was got with 6 per cent plasticizer.

Several other forms of behaviour of leather finishes have to be controlled; partly in the formulation, and partly in the mode of application and aftertreatment. These properties include gloss, hardness, colour, flexibility and 'feel'.

One of those present doubted the applicability of test results on continuous films; when the same material after application to the leather forms a largely discontinuous film. It was also asserted that pigment particle average size (say, $2 \mu$ ) is unimportant; the deciding (adverse) factor being the proportion and size of the larger aggregates of pigment. These, giving rise to marked localization of subsequent strains, might cause low adhesion and a brittle finish.

\section{Leather Making}

In the course of the conversion of raw animal hide into leather-soaking, liming, bating, tanning and so on-the aim is to control the closeness or openness of texture ('angle of weave'), the breakdown of reticular tissue, and the splitting (into 'fibrils') of the fibre-bundles.

Picturing the structure of leather as a trellis-work (in three rather than two dimensions), a closely-knit trellis, with high 'angle of weave', would be seen to present a compact collection of fibre-ends at the boundaries of the material. This was desirable where abrasion resistance is needed, as in sole-leather; and such a system is not readily deformable, and has elastic rebound. Close texture, coupled with considerable fibre splitting, would yield a somewhat more deformable material, as for example shoe upper leather.

In sole leather, the tannage is not pushed very far, and much filling material ('non-tans') incorporated; the grease content being small. In upper leather, the combined tan is higher, with less filler, and the texture internally lubricated with much grease. A tabular comparison is as follows:

\begin{tabular}{|l|c|c|c|}
\hline & Sole leather & Upper leather & Belting leather \\
\hline Angle of weave & high & $\begin{array}{c}\text { high } \\
\text { marked }\end{array}$ & $\begin{array}{c}\text { low } \\
\text { marked }\end{array}$ \\
Tan $\%$ & 24 & 24 \\
Non-tan \% & 18 & 7 & 14 \\
Grease \% & 33 & 17 & 11.5 \\
\hline
\end{tabular}

These data related to vegetable tannage.

The chemical processes of the tannery, and the sundry mechanical treatments, can be so controlled that only one factor remains out of the tanner's reach. Until the animal can be so bred and reared as to produce a standardized pelt, this last factor would most likely continue to be an independent variable.

C. A. Maunder Foster.

\section{MARINE BIOLOGICAL RESEARCH IN SOUTH AFRICA}

THE first of a series of pamphlets to be published by the Research Survey Committee of the Association of Scientific Workers of Southern Africa has recently appeared*. The work of the Committee is "intended to help in stimulating and developing research in the Union and in affording constructive suggestions for building up a more adequate and satisfactory organisation of research within the country". Dr. Wm. Edwyn Isaac, the writer of the present pamphlet, is on the staff of the Government Low Temperature Research Laboratory, where he has lately been working on problems of food technology and on South African seaweeds as sources of agar. $\mathrm{He}$ directs attention to the acute need in South Africa for basic research on marine problems and to the extreme shortage of laboratories and staff, giving excellent summaries under various headings: the fundamental cycle of life in the sea, knowledge of plankton basic to the fisheries, a brief history of fisheries research in the Union, our knowledge of chemistry and physics and of the marine biology of South African seas, certain general considerations arising out of the review of fisheries and marine biological investigations in South Africa, and, finally, a project for a marine research institute with special reference to plankton.

Marine products are among the least exploited of the Union's resources, although the fauna is a vastly rich one and there is abundance of fish. In 1934 the Board of Trade reported that the annual consumption of fish in the Union is only $4 \frac{1}{2} \mathrm{lb}$. per head of the population, and, later, C. von Bonde and Rees Davis directed attention (1942) to the small fish consumption. The corresponding values for Britain and Norway are $4 \mathrm{llb}$. and $70 \mathrm{lb}$. respectively. A sound knowledge of the marine biology and hydrology of the regions concerned is imperative, and at present only the fringe of such studies has keen approached.

The project for a research institute with special reference to plankton is a good one, including as it does suggestions for special work at first conducted from one central research institution, later spreading to several marine stations with their full number of boats. It is urged that such a marine research

* Marine Biological Research and the South African Fishing Industry. By Wm. Edwyn Isauc. Research Memorandum I, 1943. Published for the Association of Scientifle Workers of Southern Africa (Cape Town Branch) by the African Bookman, P.O. Box 3115, Capc Town. 18. 6 d. 